\title{
Screening Sugarcane Wild Accessions for Resistance to Sugarcane Mosaic Virus (SCMV)
}

\author{
M. F. Silva • M. C. Gonçalves • M. N. G. Melloni • D. Perecin • \\ M. G. A. Landell $\cdot$ M. A. Xavier $\cdot$ L. R. Pinto
}

Received: 9 March 2014/ Accepted: 1 May 2014/Published online: 10 July 2014

(C) Society for Sugar Research \& Promotion 2014

\begin{abstract}
In order to identify new sources of resistance for future introgression crosses, wild sugarcane germplasm was screened for resistance to Sugarcane mosaic virus (SCMV) under high inoculum pressure. Evaluation of symptoms by a grade scale associated with serological diagnostic by plate-trapped antigen-enzyme-linked immunosorbent assay (PTA-ELISA) with a specific antiserum were performed in 43 accessions, encompassing Saccharum officinarum, S. barberi, S. spontaneum and S. robustum species and hybrids. Differential patterns of resistance and susceptibility were observed among the Saccharum species, with $S$. officinarum followed by $S$. robustum accessions showing higher susceptibility, whereas $S$. barberi and $S$. spontaneum had the most resistant accessions. The results indicate that accessions IS76-155, IJ76-418 red, NG57-50, Ceram red, Badilla, Sac.off 8276, Fiji19, IJ76313, US57-141-5, Krakatau, IN84-58, IN84-88, IN84-82, Gandacheni, and Chin, possibly consist in good sources of resistance to mosaic.
\end{abstract}

M. F. Silva - M. N. G. Melloni - M. G. A. Landell ·

M. A. Xavier · L. R. Pinto $(\square)$

Centro de Cana IAC, Instituto Agronômico, CP 206, Ribeirão

Preto, SP CEP 14001-970, Brazil

e-mail: lurossini@iac.sp.gov.br

M. F. Silva · M. N. G. Melloni · D. Perecin

Faculdade de Ciências Agrárias e Veterinárias da Universidade Estadual Paulista, Campus Jaboticabal. Via de acesso Prof. Donato Castellani s/n, Jaboticabal, SP, Brazil

M. C. Gonçalves

Plant Virology Laboratory, Instituto Biológico, CPDSV, Av. Conselheiro Rodrigues Alves 1252, São Paulo, SP 04014-002, Brazil
Keywords Sources of resistance - Saccharum spp. · Sugarcane mosaic

\section{Introduction}

Mosaic is one of the most disseminated viruses in sugarcane, maize, sorghum and other poaceus worldwide, being caused by viruses of Sugarcane mosaic virus (SCMV) subgroup of the family Potyviridae (Gonçalves et al. 2012; Viswanathan and Mohanraj 2001). Six distinct species of the genus Potyvirus, including SCMV, Sorghum mosaic virus (SrMV), Johnsongrass mosaic virus (JGMV), Maize dwarf mosaic virus (MDMV), Pennisetum mosaic virus (PenMV), Zea mosaic virus (ZeMV), and one of the new genus Poacevirus (Li et al. 2011; Parameswari et al. 2013; Viswanathan et al. 2008; Xu et al. 2010), Sugarcane streak mosaic virus (SCSMV) are recognized in this group. Under natural conditions, there are reports only of SCMV, SrMV and SCSMV isolated from sugarcane, whereas the last four viruses have never been isolated from this crop (Chatenet et al. 2005). It was reported that the single potyviridae causing mosaic in sugarcane in Brazil is SCMV (Gonçalves et al. 2011, 2007, 2004), despite JGMV has been recently reported infecting Pennisetum purpureum, a tropical grass used for pasture in the country (Silva et al. 2013).

The disease is responsible for varying economic impacts on sugarcane, depending on the virus species and strain and on the sugarcane variety. In Brazil, the disease is relatively controlled due to action of breeding programs and practical field approaches, but screening for resistance to mosaic remains as an essential step in reason of factors like favorable epidemiological conditions to mosaic dissemination and recent descriptions of new isolates, which reinforce the current importance of the disease (Gonçalves et al. 2012, 2007, 2004). 
The emergence of new virus strains reinforces the need of searching for new sources of resistance in sugarcane germplasm collections in order to support the development of new sugarcane varieties resistant to SCMV. Such studies were performed for SCMV strain H (Grisham et al. 1992), for SrMV HH (Li et al. 2013) with artificial inoculation under greenhouse conditions and for Sugarcane yellow leaf virus (SCYLV), another important virus infecting sugarcane, under natural infection conditions (Comstock et al. 2001).

Sugarcane belongs to the genus Saccharum, tribe Andropogoneae of the family Poaceae. The genus includes six species named Saccharum officinarum, S. sinense, S. barberi, S. edule, S. spontaneum and $S$. robustum that jointly with the related genera Erianthus, Miscanthus, Narenga and Sclerostachya, constitutes the 'Saccharum' complex (Daniels and Daniels 1975) which represents sources of genetic variation for sugarcane breeding programs worldwide. Modern sugarcane varieties have an interspecific origin derived from introgressions with the wild species $S$. spontaneum and $S$. robustum into the cultivated species $S$. officinarum, S. sinense and S. barberi (D'Hont et al. 2008; Grivet et al. 2006; Irvine 1999; Grivet and Arruda 2002). The major limitation of sugarcane breeding is its narrow genetic base, as all the modern varieties descend from a few ancestors or foundation clones (Deren 1995; Berding and Roach 1987).

In Brazil, sugarcane breeding programs use mainly commercial varieties as parents (Barbosa 2001; Duarte Filho et al. 2010) in their crosses, which have a common genetic basis. Besides the need to broaden the genetic basis of sugarcane, the current focus on biomass for ethanol and energy production, has stimulated sugarcane breeders to start introgression programs involving crosses between commercial varieties and wild accessions of $S$. spontaneum and $S$. robustum. Therefore, screening sugarcane wild accessions for resistance to SCMV will help breeders in the choice of appropriate accessions to be used as parents in the introgression programs either for bioenergy or sugar production. The present study aimed to evaluate SCMV infection in some accessions of the germplasm collection maintained at the Campinas Agronomic Institute (IAC) Sugarcane Research Centre, Brazil, in order to identify possible sources of resistance and guide future introgression crosses.

\section{Materials and Methods}

\section{Genotype Panel}

The resistance to mosaic was evaluated in 43 accessions, which include $30 \mathrm{~S}$. officinarum, $3 \mathrm{~S}$. barberi, $6 \mathrm{~S}$. spontaneum and $4 S$. robustum accessions maintained at the IAC Sugarcane Breeding Station, Brazil (Table 1).

Experimental Design and Evaluation of Mosaic Incidence and Severity

The experiment was conducted in complete randomized block design with three replicates and $1 \mathrm{~m}$ plots spaced $1 \mathrm{~m}$ between plots and $1.5 \mathrm{~m}$ between rows, adopting IACSP95-5000 and IACSP93-046 varieties as checks. The field experiment was installed in October 2011 in an area previously known as of high mosaic and sugarcane aphid incidence in Ribeirão Preto, São Paulo Brazil. Sugarcane accessions were evaluated for mosaic incidence and severity under natural infection conditions in 6 months first ratoon cane, in May 2013. A slightly modified symptom grade scale based in the one described by Pinto et al. (2013) was used to evaluate the severity of mosaic symptoms, as following: symptom absence (0); mild mosaic in one or more leaves (1); intense mosaic in two or more leaves (2); generalized intense mosaic, along with reduction in plant growth (3).

\section{SCMV Detection by PTA-ELISA}

In order to confirm the virus infection, the serological test plate-trapped antigen-enzyme-linked immunosorbent assay (PTA-ELISA) with an antiserum specific to SCMV was carried out in the second youngest sugarcane leaf collected from each accession. Leaf samples were grounded in carbonate buffer $0.05 \mathrm{M}, \mathrm{pH}$ 9.6, 1:10 ratio (weight: volume), to cover ELISA plates. The antiserum was diluted in phosphate buffered saline with $0.05 \%$ Tween-20, $2 \%$ polyvinylpyrrolidone and $0.2 \%$ ovalbumin (PBS-TPO) 1:6000, with $1 \%$ of skim milk powder and the alkaline phosphatase-conjugated "anti-rabbit" IgG was diluted 1:3000. The enzyme substrate $p$-nitrophenylphosphate (PNPP) was used in the concentration of $1 \mathrm{mg} / \mathrm{ml}$ of diethanolamine buffer $\mathrm{pH}$ 9.8. Four absorbance readings at $405 \mathrm{~nm}\left(\mathrm{~A}_{405 \mathrm{~nm}}\right)$ were done in an ELISA plate reader at every $20 \mathrm{~min}$. Samples with $\mathrm{A}_{405 \mathrm{~nm}}$ reading mean three times above the negative control's reading means were considered as SCMV infected.

\section{Statistical Analysis}

Variance analysis was performed on grade symptoms results, using the Statistical Analysis System (SAS) software (SAS 2008) general linear model procedure (Proc GLM), and means comparisons by Least significant difference test (LSD Test) at $p<0.05$, according to the statistical model: $Y_{\mathrm{ijk}}=\mu+\mathrm{B}_{\mathrm{j}}+\mathrm{S}_{\mathrm{i}}+\mathrm{G}_{\mathrm{k}(\mathrm{i})}+\mathrm{e}_{\mathrm{ijk}}$, where $\mathrm{Y}_{\mathrm{ijk}}=$ observation of kth genotype (accession) nested to 
Table 1 List of sugarcane accessions from the IAC germplasm collection and their respective originating species

\begin{tabular}{|c|c|c|c|}
\hline Genotype & Species & Genotype & Species \\
\hline Badilla java & F1 (S. officinarum) & IS76-155 & F1 (S. officinarum) \\
\hline IJ76-560 & F1 $($ S. officinarum $\times$ ?) & IJ76-418 red & F1 (S. officinarum) \\
\hline NG77-18 & F1 (S. officinarum) & NG57-50 & Hybrid $(S$. officinarum $) \times ?$ \\
\hline NG57-213 & F1 (S. officinarum) & Ceram red & S. officinarum \\
\hline Caina fita & F1 (S. officinarum) & Badilla & S. officinarum x NG96 \\
\hline Pitu & F1 (S. officinarum) & Sac. off. 8276 & Hybrid $(S$. officinarum $\times$ ?) \\
\hline Caiana & F1 (S. officinarum) & Fiji19 & F1 (S. officinarum) \\
\hline Formosa & F1 (S. officinarum $\times$ ?) & IJ76-313 & F1 (S. officinarum) \\
\hline IN84-126 & F1 (S. officinarum) & NG57-12 & S. robustum \\
\hline Manteiga & F2 [(F1) S. officinarum $\mathrm{x}$ ?] & IM76-229 & S. robustum \\
\hline Ajax & F2 (S. officinarum) & IJ76-293 & S. robustum $\times$ ? \\
\hline IJ76-566 & F1 $($ S. officinarum $\times$ ?) & US57-141-5 & S. robustum \\
\hline IJ76-317 & F1 $($ S. officinarum $\times$ ?) & SES205A & S. spontaneum \\
\hline NG21-21 & F1 (S. officinarum) & IN84-58 & S. spontaneum $\times$ ? \\
\hline IJ76-325 & F1 $($ S. officinarum $\times$ ?) & Krakatau & S. spontaneum \\
\hline Sabura & Hybrid $(S$. officinarum $\times$ ?) & US851008 & S. spontaneum $\times$ US60-313 \\
\hline White transp. & S. officinarum & IN84-88 & S. spontaneum \\
\hline Cana alho & S. officinarum & IN84-82 & S. spontaneum $\times$ ? \\
\hline MZ151 & F1 (S. officinarum) & Gandacheni & S. barberi $\times$ ? \\
\hline IN84-105 & F1 $($ S. officinarum $\times$ ?) & Chin & S. barberi $\times$ ? \\
\hline Caiana risc. & F1 (S. officinarum) & Chunnee & S. barberi \\
\hline Zopilota & S. officinarum $\times$ ? & & \\
\hline
\end{tabular}

ith specie in jth block, $\mu=$ overall mean, $B_{j}=$ effect of $j$ th block, $\mathrm{S}_{\mathrm{i}}=$ effect of ith specie, $\mathrm{G}_{\mathrm{k}}=$ effect of kth genotype nested to ith specie, and $\mathrm{e}_{\mathrm{ij}}=$ random error, estimating the experimental variance. Data were presented as grade mean and $\ln (x+5)$ transformed, in order to approach the normal distribution (Berry 1987).

The accessions with maximum grade from 2 to 3 were classified as susceptible. Accessions with maximum grade of 1 were classified as intermediary. Accessions without mosaic symptoms were classified as resistant; even those with positive results in PTA-ELISA, characterizing latent infections, but only accessions free from SCMV were pointed out as sources of resistance for future crosses.

\section{Results and Discussion}

Variance analysis showed significant values $(p<0.01)$ for specie and accession nested to species, whereas non-significant effect was observed for block, indicating variability among accessions and species. Unfolding the variance within species, significant value $(p<0.01)$ was observed for $S$. officinarum, indicating variability in response to mosaic infection among accessions within this specie, while accessions within $S$. barberi, $S$. robustum and $S$. spontaneum did not vary significantly (Table 2). Accessions from S. officinarum, was
Table 2 Variance analysis of mosaic symptoms grades in accessions from the IAC germplasm collection

\begin{tabular}{lrrl}
\hline F.V. & D.F. & Q.M. & F \\
\hline Block & 1 & 0.038 & $2.41^{\mathrm{ns}}$ \\
Specie & 3 & 0.102 & $6.45^{* *}$ \\
Genotype nested in species (sp) & 39 & 0.036 & $2.27^{* *}$ \\
S. barberi & 2 & 0.000 & $0.00^{\mathrm{ns}}$ \\
S. officinarum & 29 & 0.045 & $2.76^{* *}$ \\
S. robustum & 3 & 0.030 & $1.83^{\mathrm{ns}}$ \\
S. spontaneum & 5 & 0.000 & $0.00^{\mathrm{ns}}$ \\
Resídual & 38 & 0.016 & \\
CV $(\%)$ & & & 7.29 \\
\hline
\end{tabular}

$\mathrm{ns}=p>0.05$

$s p$ specie

$* * p<0.01$

the most susceptible according to LSD test $(p<0.05)$, followed by $S$. robustum, while $S$. spontaneum and $S$. barberi were resistant (Table 3). The most susceptible accessions, according to the LSD test ( $p<0.05$ ) were IJ76-560 and IN84126, followed by Ajax, NG57-213, NG77-18 and Caiana fita, all belonging to $S$. officinarum (Table 4). According to Koike and Gillaspie (1989) within the genus Saccharum and depending on the SCMV strain involved, S. officinarum is the most susceptible to mosaic, while $S$. barberi and $S$. robustum 
Table 3 Mean comparisons of Saccharum species of mosaic symptoms grade by LSD test $(p<0.05)$

\begin{tabular}{llll}
\hline Species & Mean $^{\mathrm{a}}$ & Mean $^{\mathrm{b}}$ & \\
\hline S. officinarum & 0.953 & $(1.765)$ & $\mathrm{a}$ \\
S. robustum & 0.500 & $(1.697)$ & $\mathrm{ab}$ \\
S. spontaneum & 0.000 & $(1.609)$ & $\mathrm{b}$ \\
S. barberi & 0.000 & $(1.609)$ & $\mathrm{b}$ \\
\hline
\end{tabular}

a, b means with the same letter are not significantly different

${ }^{a}$ Non transformed data

${ }^{\mathrm{b}} \ln (\mathrm{x}+5)$ transformed data

are moderately susceptible, $S$. sinense and $S$. spontaneum are resistant. On the other hand, in early reports, accessions of $S$. spontaneum were immune to SCMV with few exceptions, attesting the resistance of this species (Summers et al. 1948; Brandes et al. 1939; Brandes and Sartoris 1936; Jeswiet 1930). In subsequent studies, several accessions of $S$. spontaneum were found to be susceptible to SCMV, possibly due to the development of new strains of the virus (Koike 1980; Abbott and Todd 1963). Differences in the percentage means of infection by SCMV strain $\mathrm{H}$ were observed in sugarcane accessions by Grisham et al. (1992), being accessions of Erianthus, S. spontaneum, S. barberi and S. sinense the most resistant and accessions of $S$. robustum the most susceptible, while interspecific hybrids and accessions of $S$. offcinarum were intermediate. The authors also observed differences in accessions response within each evaluated taxon, with a considerable range of mosaic incidence among accessions of S. spontaneum. Li et al. (2013) observed that 17 out of the 37 tested $S$. spontaneum accessions were highly to moderately resistant to SrMV, being pointed, along with Erianthus arundinaceus, as valuable germplasm in terms of resistance to SrMV HH.

To date, the response to SCMV of the accessions investigated in the present study was unreported. In

Table 4 Mean comparisons of the accessions for mosaic symptoms grade by LSD test $(p<0.05)$

\begin{tabular}{|c|c|c|c|c|c|c|c|c|c|}
\hline Accessions & Species $^{\mathrm{a}}$ & Mean $^{\mathrm{b}}$ & Mean $^{\mathrm{c}}$ & & Genotype & Species $^{\mathrm{a}}$ & Mean $^{\mathrm{b}}$ & Mean $^{\mathrm{c}}$ & \\
\hline IJ76-560 & S. off. & 3.000 & $(2.079)$ & A & $\begin{array}{c}\text { Sac.off. } \\
8276\end{array}$ & S. off. & 0.000 & (1.609) & d \\
\hline IN84-126 & S. off. & 3.000 & $(2.079)$ & A & NG21-21 & S. off. & 0.000 & (1.609) & d \\
\hline Ajax & S. off. & 2.464 & $(2.010)$ & $\mathrm{Ab}$ & Cana alho & S. off. & 0.000 & (1.609) & d \\
\hline NG57-213 & S. off. & 2.464 & $(2.010)$ & $\mathrm{Ab}$ & IN84-105 & S. off. & 0.000 & (1.609) & $\mathrm{d}$ \\
\hline NG77-18 & S. off. & 2.464 & $(2.010)$ & $\mathrm{Ab}$ & Zopilota & S. off. & 0.000 & (1.609) & $\mathrm{d}$ \\
\hline Caina fita & S. off. & 2.464 & $(2.010)$ & $\mathrm{Ab}$ & IS76-155 & S. off. & 0.000 & (1.609) & $\mathrm{d}$ \\
\hline IJ76-325 & S. off. & 2.000 & $(1.946)$ & $\mathrm{Abc}$ & IJ76-418 red & S. off. & 0.000 & (1.609) & $\mathrm{d}$ \\
\hline IJ76-293 & S. rob. & 1.450 & (1.864) & $\mathrm{Abc}$ & NG57-50 & S. off. & 0.000 & (1.609) & $\mathrm{d}$ \\
\hline Caiana & S. off. & 1.450 & (1.864) & $\mathrm{Abc}$ & Badilla & S. off. & 0.000 & (1.609) & $\mathrm{d}$ \\
\hline Pitu & S. off. & 1.000 & (1.792) & Abcd & Fiji19 & S. off. & 0.000 & (1.609) & $\mathrm{d}$ \\
\hline Manteiga & S. off. & 1.000 & (1.792) & Abcd & IJ76-313 & S. off. & 0.000 & (1.609) & $\mathrm{d}$ \\
\hline Badilla Java & S. off. & 1.000 & $(1.792)$ & Abcd & IM76-229 & S. rob. & 0.000 & (1.609) & $\mathrm{d}$ \\
\hline Formosa & S. off. & 1.000 & (1.792) & Abcd & US85-1008 & S. spo. & 0.000 & (1.609) & $\mathrm{d}$ \\
\hline Caiana risc. & S. off. & 0.732 & $(1.746)$ & Bcd & SES205A & S. spo. & 0.000 & (1.609) & $\mathrm{d}$ \\
\hline $\begin{array}{l}\text { White } \\
\text { transp. }\end{array}$ & S. off. & 0.732 & $(1.746)$ & Bcd & Krakatau & S. spo. & 0.000 & (1.609) & $\mathrm{d}$ \\
\hline IJ76-317 & S. off. & 0.732 & (1.746) & Bcd & IN84-58 & S. spo. & 0.000 & (1.609) & $\mathrm{d}$ \\
\hline IJ76-566 & S. off. & 0.732 & (1.746) & Bcd & IN84-88 & S. spo. & 0.000 & (1.609) & $\mathrm{d}$ \\
\hline Sabura & S. off. & 0.732 & (1.746) & Bcd & IN84-82 & S. spo. & 0.000 & (1.609) & $\mathrm{d}$ \\
\hline MZ151 & S. off. & 0.732 & $(1.746)$ & Bcd & Chunnee & S. bar. & 0.000 & (1.609) & $\mathrm{d}$ \\
\hline NG57-12 & S. rob. & 0.414 & (1.689) & $\mathrm{Cd}$ & Gandacheni & S. bar. & 0.000 & (1.609) & $\mathrm{d}$ \\
\hline US57-141-5 & S. rob. & 0.000 & (1.609) & $\mathrm{D}$ & Chin & S. bar. & 0.000 & (1.609) & $\mathrm{d}$ \\
\hline Ceram red & S. off. & 0.000 & (1.609) & $\mathrm{D}$ & & & & & \\
\hline
\end{tabular}

$\mathrm{a}, \mathrm{b}, \mathrm{c}, \mathrm{d}$ means with the same letter are not significantly different

$\mathrm{ns}=p>0.05$

$* * p<0.01$

${ }^{a}$ Species: (S. off.) S. officinarum, (S. rob.) S. robustum, (S. spo.) S. spontaneum, (S. bar.) S. barberi

b Non transformed data

${ }^{c} \ln (x+5)$ transformed data 
Table 5 Mosaic symptoms grades and PTA-ELISA specific for SCMV of sugarcane accessions after 6 months of exposition in the experimental field

\begin{tabular}{|c|c|c|c|c|c|c|c|}
\hline Genotype & ELISA $^{\mathrm{a}}$ & Maximum grade ${ }^{b}$ & Mosaic resp..$^{c}$ & Accessions & ELISA $^{\mathrm{a}}$ & Maximum grade ${ }^{b}$ & Mosaic resp. ${ }^{c}$ \\
\hline \multicolumn{8}{|c|}{ S. officinarum accessions } \\
\hline Badilla Java & + & 1 & I & Sabura & + & 2 & $S$ \\
\hline IJ76-560 & + & 3 & $S$ & White transp. & + & 2 & $S$ \\
\hline NG77-18 & + & 3 & S & Cana alho & + & 0 & $\mathrm{R}$ \\
\hline NG57-213 & + & 3 & S & MZ151 & + & 2 & $S$ \\
\hline Caina fita & + & 3 & S & IN84-105 & + & 0 & $\mathrm{R}$ \\
\hline Pitu & + & 1 & I & Caiana risc. & + & 2 & $S$ \\
\hline Caiana & + & 2 & S & Zopilota & + & 0 & $\mathrm{R}$ \\
\hline Formosa & + & 3 & S & IS76-155 & - & 0 & $\mathrm{R}$ \\
\hline IN84-126 & + & 3 & S & IJ76-418 red & - & 0 & $\mathrm{R}$ \\
\hline Manteiga & + & 3 & S & NG57-50 & - & 0 & $\mathrm{R}$ \\
\hline Ajax & + & 3 & S & Ceram red & - & 0 & $\mathrm{R}$ \\
\hline IJ76-566 & + & 2 & $S$ & Badilla & - & 0 & $\mathrm{R}$ \\
\hline IJ76-317 & + & 2 & $S$ & Sac.off. 8276 & - & 0 & $\mathrm{R}$ \\
\hline NG21-21 & + & 0 & $\mathrm{R}$ & Fiji19 & - & 0 & $\mathrm{R}$ \\
\hline IJ76-325 & + & 2 & $S$ & IJ76-313 & - & 0 & $\mathrm{R}$ \\
\hline \multicolumn{8}{|c|}{ S. robustum accessions } \\
\hline IJ76-293 & + & 2 & S & IM76-229 & + & 0 & $\mathrm{R}$ \\
\hline NG57-12 & + & 1 & I & US57-141-5 & - & 0 & $\mathrm{R}$ \\
\hline \multicolumn{8}{|c|}{ S. spontaneum accessions } \\
\hline US85-1008 & + & 0 & $\mathrm{R}$ & Krakatau & - & 0 & $\mathrm{R}$ \\
\hline SES205A & + & 0 & $\mathrm{R}$ & IN84-88 & - & 0 & $\mathrm{R}$ \\
\hline IN84-58 & - & 0 & $\mathrm{R}$ & IN84-82 & - & 0 & $\mathrm{R}$ \\
\hline \multicolumn{8}{|c|}{ S. barberi accessions } \\
\hline Chunnee & - & 0 & $\mathrm{R}$ & Chin & - & 0 & $\mathrm{R}$ \\
\hline Gandacheni & - & 0 & $\mathrm{R}$ & & & & \\
\hline
\end{tabular}

${ }^{a}$ PTA-ELISA results $(-)$ negative and $(+)$ positive

${ }^{\mathrm{b}}$ Higher grade observed for mosaic symptoms

c $S$ Susceptible, $I$ Intermediary and $R$ Resistant

addition, the strain SCMV-Rib1 that prevails in the experimental area where the trials were conducted was responsible for mosaic outbreaks in the state of São Paulo in cultivars previously thought to be resistant to mosaic (Gonçalves et al. 2007). The response to natural infection by mosaic observed among Saccharum species in our study was similar to that reported by Koike and Gillaspie (1989) for $S$. officinarum and S. robustum and to the results presented by Grisham et al. (1992) for $S$. barberi accessions.

The combined results from grade scale symptoms and PTA-ELISA indicate that the accessions IS76-155, IJ76-418 red, NG57-50, Ceram red, Badilla, Sac. off. 8276, Fiji19, IJ76-313 (S. officinarum); accession US 57-141-5 (S. robustum); accessions Krakatau, IN84-58, IN84-88 and IN84-82 (S. spontaneum); accessions Chunnee, Gandacheni and Chin (S. barberi) were SCMV free, characterizing promising sources for selecting resistance to mosaic. Although being the most susceptible specie, 8 out of the 30 tested $S$. officinarum clones were pointed out as source of resistance. The higher number of $S$. officinarum accessions and the polycross origin of NG57-50 and Sac. off. 8296, which may have involved species resistant to mosaic, had contributed to the range of responses to mosaic here observed. Besides the expected variation within species, according to the literature, future studies involving a higher number of accessions by specie are required to a better understanding of specie response to mosaic. Despite symptomless, the accessions NG21-21, Cana alho, IN84-105, Zopilota, US85-1008 and SES205A had the presence of SCMV diagnosed by PTAELISA (Table 5), what partly prevents their recommendation for future crosses focusing on resistance to mosaic.

As the mosaic disease impairs photosynthetic efficiency, reduction in growth and yield parameters directly affecting biomass and consequently ethanol production are usually observed in infected crops (Viswanathan and Balamuralikrishnan 2005), therefore selection of wild S. spontaneum 
and $S$. robustum accessions resistant to mosaic to be used as parents would be highly useful in the introgression programs focused in increase of biomass.

Acknowledgments The present research was financed by Fundação de Amparo a Pesquisa do Estado de São Paulo (FAPESP/BIOEN 2008/56146-5) and IAC (Instituto Agronômico de Campinas). M.F.S. receive Master fellowship from CAPES.

\section{References}

Abbott, E.V., and E.H. Todd. 1963. Mosaic in clones of Saccharum spontaneum and in Kassoer. Proceedings of the International Society of Sugarcane Technologists 11: 753-755.

Barbosa, M.H.P. 2001. Study of genetic divergence in sugarcane varieties grown in Brazil using the parentage coeficiente. International Sugar Journal, London 103(1231): 294-295.

Berding, N., and B.T. Roach. 1987. Germplasm collection, maintenance and use. In Sugarcane improvement through breeding, ed. D.J. Heinz, 143-210. Amsterdam: Elsevier Press.

Berry, D.A. 1987. Logarithmic transformations in ANOVA. Biometrics 43: 439-456.

Brandes, E.W., G.B. Sartoris, and C.O. Grassl. 1939. Assembling and evaluating wild forms of sugar cane and closely related plants. Proceedings of the International Society of Sugar Cane Technologists 6: 128-154.

Brandes, E.W., and G.B. Sartoris. 1936. Sugarcane: Its origin and improvement. In Yearbook of agriculture, ed. D.C. Washington, 561-623. Washington: Government Printing Office.

Chatenet, M., C. Mazarin, J.C. Girard, E. Fernadez, D. Gargani, G.P. Rao, M. Royer, B.E.L. Lockhart, and P. Rott. 2005. Detection of sugarcane streak mosaic virus in sugarcane from several Asian countries. Proceedings of the International Society of Sugarcane Technologists 25: 656-662.

Comstock, J.C., J.D. Miller, and R.J. Schnell. 2001. Incidence of sugarcane yellow leaf virus in clones maintained in the world collection of sugarcane and related grasses at the United States national repository in Miami, Florida. Sugar Tech 3(4): 128-133.

Daniels, J., and C.A. Daniels. 1975. Geographical, historical and cultural aspects of the origin of the Indian and Chinese sugarcanes S. barberi and S. sinense. Sugarcane Breeding Newsletters 36: 4-23. ISSN 1028-1193.

Deren, C.W. 1995. Genetic base of U.S. Mainland sugarcane. Crop Science 35: 1195-1199.

D’Hont, A., G.M. Souza, M. Menossi, M. Vinentz, M.A. Van Sluys, J.C. Glaszmann, and E. Ulian. 2008. Sugarcane: A major source of sweetness, alcohol, and bio-energy. In Genomics of tropical crop plants, ed. P.H. Moore, and R. Ming, 483-513. New York: Springer. ISBN: 9781441924339.

Duarte Filho, L.S.C., P.P. Silva, J.M. Santos, G.V.S. Barbosa, C.E. Ramalho Neto, L. Soares, J.C.F. Andrade, and C. Almeida. 2010. Genetic similarity among genotypes of sugarcane estimated by SSR and coefficient of parentage. Sugar Tech 12: 145-149.

Gonçalves, M.C., L.R. Pinto, S.C. Souza, and M.G.A. Landell. 2012. Virus diseases of sugarcane. A constant challenge to sugarcane breeding in Brazil. Functional Plant Science \& Biotechnology 6: 108-116.

Gonçalves, M.C., D.M. Galdeano, I.G. Maia, and C.M. Chagas. 2011. Genetic variability of Sugarcane mosaic virus genotypes causing maize mosaic in Brazil. Pesquisa Agropecuária Brasileira 46: 362-369.

Gonçalves, M.C., A.S. Santos, L.G. Maia, C.M. Chagas, and R. Harakava. 2007. Characterization of an isolate of sugarcane mosaic virus breaking down resistance of commercial sugarcane varieties. Fitopatologia Brasileira 32: 32-39.

Gonçalves, M.C., Y.J.C.B. Moreira, I.G. Maia, A.S. Santos, G.M. Fantin, and A. Chaves. 2004. Identificação e caracterização de isolados pertencentes ao subgrupo do Sugarcane mosaic virus no estado de São Paulo. Fitopatologia Brasileira 29: 129.

Grisham, M.P., D.M. Burner, and B.L. Legendre. 1992. Resistance to the $\mathrm{H}$ strain of Sugarcane mosaic virus among wild forms of sugarcane and relatives. Plant Disease 76: 360-362.

Grivet, L., J.C. Glaszmann, and A. D́Hont. 2006. Molecular evidence for sugarcane evolution and domestication. In Darwin's Harvest. New approaches to the origins, evolution and conservation, ed. T. Moley, N. Zerega, and H. Cross, 49-66. West Sussex: Columbia University Press. ISBN 9780231133166.

Grivet, L., and P. Arruda. 2002. Sugarcane genomics: Depicting the complex genome of an important tropical crop. Current Opinion in Plant Biology 5: 122-127.

Irvine, J.E. 1999. Saccharum Species as Horticultural Classes. [s.I.]. Theoretical and Applied Genetics 98(2): 186-194. ISSN 0040-5752.

Jeswiet, J. 1930. The development of selection and breeding of the sugar cane in Java. [s.I.]: Proceedings of the International Society of Sugar Cane Technologists 17: 1523-1527.

Koike, H. and A.G. Gillaspie Jr. 1989. Mosaic. In: Diseases of Sugarcane: Major Diseases, eds. Ricaud C., B.T. Egan, A.G. Gillaspie Jr and C.G. Hughes, 301-322. Amsterdam, the Netherlands: Science Publishers.

Koike, H. 1980. Evidence of resistance in Saccharum spontaneum and Saccharum-related genera to sugarcane mosaic virus strains $\mathrm{H}$ and I. [s.I.]. Proceedings of the International Society of Sugar Cane Technologists 17: 1523-1527.

Li, W., Z. He, S. Li, Y. Huang, Z. Zhang, D. Jiang, X. Wang, and Z. Luo. 2011. Molecular characterization of a new strain of sugarcane streak mosaic virus (SCSMV). Archives of Virology 156: 2101-2104.

Li, W., X. Wang, Y. Huang, H. Shan, Z. Luo, X. Ying, R. Zhang, K. Shen, and J. Yin. 2013. Screening sugarcane germplasm resistant to Sorghum mosaic virus. Crop Protection 43: 27-30.

Parameswari, B., K. Bagyalakshmi, R. Viswanathan, and C. Chinnaraja. 2013. Molecular characterization of Indian sugarcane streak mosaic virus isolate. Virus Genes 46: 186-189.

Pinto, L.R., M.C. Gonçalves, D.M. Galdeano, D. Perecin, C.N.F. Medeiros and M.G. Landell. 2013. Preliminary investigation of sugarcane mosaic virus resistance and marker association in a sugarcane family sample derived from a bi-parental cross. Proceedings International Society Sugarcane Technologists 28: 523-528.

SAS Institute. 2008 SAS/STAT user's guide, version 9.2 SAS, Cary.

Silva, K.N., C. Nicolini, M.S. Silva, C.D. Fernandes, T. Nagata, and R.O. Resende. 2013. First report of Johnsongrass mosaic virus (JGMV) infecting Pennisetum purpureum in Brazil. Plant Disease 97: 1003 .

Summers, E. M., E. W. Brandes and R.D. Rands. 1948. Mosaic of sugar cane in the United States, with special reference to strains of the virus, 124. U.S: Dep. Agric. Tech. Bull. 955.

Viswanathan, R., and D. Mohanraj. 2001. Detection of sugarcane viral diseases by serological, techniques. In Sugarcane pathology, vol. 11, ed. G.P. Rao, R.E. Ford, M.S. Tosic, and D.S. Teakle, 195-208. Enfield: Virus and Phytoplasma Diseases, Science Publishers.

Viswanathan, R., and M. Balamuralikrishnan. 2005. Impact of mosaic infection on growth and yield of sugarcane. Sugar Tech 7: 61-65.

Viswanathan, R., M. Balamuralikrishnan, and R. Karuppaiah. 2008. Characterization and genetic diversity of sugarcane streak mosaic virus causing mosaic in sugarcane. Virus Genes 36: 553-564.

Xu, D.L., G.H. Zhou, Y.J. Xie, R. Mock, and R. Li. 2010. Complete nucleotide sequence and taxonomy of Sugarcane streak mosaic virus, member of a novel genus in the family Potyviridae. Virus Genes 40: 432-439. 